\title{
Decreased ligand affinity rather than glucocorticoid receptor down-regulation in patients with endogenous Cushing's syndrome
}

\author{
Nannette A T M Huizenga ${ }^{1}$, Wouter W De Herder ${ }^{1}$, Jan W Koper ${ }^{1}$, Pieter de Lange ${ }^{1}$, Aart Jan v d Lely ${ }^{1}$, \\ Albert O Brinkmann ${ }^{2}$, Frank $\mathrm{H}$ de Jong ${ }^{1}$ and Steven W J Lamberts ${ }^{1}$ \\ Departments of ${ }^{1}$ Internal Medicine III and ${ }^{2}$ Endocrinology and Reproduction, Dijkzigt University Hospital Rotterdam, Dr Molewaterplein 40 , \\ 3015 GD Rotterdam, The Netherlands \\ (Correspondence should be addressed to N A T M Huizenga, Department of Internal Medicine III, Dijkzigt University Hospital, Afdeling 4 zuid, \\ Dr. Molewaterplein 40, 3015 GD Rotterdam, The Netherlands; Email: Huizenga@inw3.AZR.NL)
}

\begin{abstract}
Objective: Glucocorticoids (GCs) serve a variety of important functions throughout the body. The synthesis and secretion of GCs are under the strict influence of the hypothalamo-pituitary-adrenal axis. The mechanisms of action of GCs are mediated by the intracellular glucocorticoid receptor (GR). Over the years, many studies have been performed concerning the regulation of GR expression by GC concentrations.

Methods: In the present study, we determined the characteristics of the GR in peripheral mononuclear blood leukocytes (PBML) from thirteen patients with endogenous Cushing's syndrome and fifteen control subjects, using a whole cell dexamethasone binding assay. Furthermore, cortisol concentrations were determined in order to investigate a possible relationship between serum cortisol levels and receptor characteristics.

Results: There were no differences in mean receptor number between patients and controls. On the other hand, a significantly lower ligand affinity was identified in cells from patients with Cushing's syndrome compared with controls. A complete normalisation of the ligand affinity was observed after treatment in the only patient tested in this respect, whereas the receptor number was not affected. In patients, there was a statistically significant negative correlation between cortisol concentrations and ligand affinity, which was not found in controls.

Conclusion: Receptor down-regulation does not occur in PBML from patients with endogenous Cushing's syndrome. On the other hand, there seems to be a diminished ligand affinity which possibly reflects receptor modification in response to exposure to the continuously high cortisol levels in patients with Cushing's syndrome. This assumption is substantiated by the fact that in one patient a normalisation of the ligand affinity after complete remission of the disease was seen.
\end{abstract}

European Journal of Endocrinology $142472-476$

\section{Introduction}

Glucocorticoids (GCs) serve a variety of important functions throughout the body. GCs affect metabolism by maintaining plasma glucose levels. They are important in the regulation of fat metabolism, mediate stress response, influence the immune and central nervous system and have numerous effects on development and differentiation (1). The regulation of serum GC concentrations is under the influence of the hypothalamo-pituitary-adrenal axis (HPA-axis) (2). Hypothalamic corticotrophin releasing hormone $(\mathrm{CRH})$ is transported to the pituitary which, in response, secretes corticotrophin (ACTH) into the hypophysial portal system. The adrenal gland is stimulated by ACTH to synthesise and secrete cortisol. Cortisol, in its turn, exerts a negative feedback on both the hypothalamic and the pituitary level in order to complete a negative feedback loop. In this way, a perfect balance between cortisol requirement and cortisol secretion can be achieved. The HPA-axis is under the influence of many other systems. In cases of stress, for example, the HPA-axis is activated, resulting in higher concentrations of GC (2).

Glucocorticoids exert their effects via the cytoplasmic glucocorticoid receptor (GR), which is a member of the family of intracellular steroid hormone receptors to which receptors for vitamin $\mathrm{D}$, retinoic acid and thyroid hormone also belong $(3,4)$. The structural organisation of the GR is characterised by a short and highly 
conserved cysteine rich central region constituting the DNA binding domain, a relatively well conserved carboxy terminal domain which is important for both hormone binding and translocation, and a poorly conserved amino terminal region containing the transactivation domains responsible for gene activation (5). It is now well established that the ability of GCs to exert their biological effects requires the presence of a sufficient amount of intact receptor molecules $(4,6)$. There is evidence that GRs undergo down-regulation after exposure to ligand in vitro, in animals and men (7, 8). This receptor down-regulation is supposed to be an additional form of negative feedback regulation of GC action, apart from the regulation of GC serum levels by the HPA-axis (6). Nevertheless, the mechanisms of possible receptor down-regulation are poorly understood, and many discrepancies in different studies have been reported. Moreover, most studies investigating receptor down-regulation were performed in vitro or, when performed in vivo, used pharmacological amounts of GCs. In the present study, we investigated GR characteristics in patients with endogenous Cushing's syndrome. The aim was to identify whether GR downregulation in peripheral blood mononuclear leukocytes (PBML) from these patients with long term hypercortisolism who lack a diurnal rhythm of serum cortisol concentrations does occur. We found no receptor downregulation, but a statistically significant decrease in ligand affinity for the receptor, which appeared to be closely related to the serum cortisol concentrations. Furthermore, the ligand affinity returned to normal in a patient after successful treatment for Cushing's disease.

\section{Patients and methods}

\section{Patients and control subjects}

Thirteen patients, seven females and six males, with clinical and biochemical Cushing's syndrome were included. In all patients, 24-h urinary cortisol excretion was above the upper limits of normal. Furthermore, they showed insufficient adrenal cortisol suppression in the overnight $1 \mathrm{mg}$ dexamethasone suppression test, and diurnal rhythms of serum cortisol concentrations were absent in all patients. Nine of the patients had Cushing's disease, two had an adrenal cortisolproducing carcinoma, one had ectopic ACTH secretion and one had an adrenal cortisol-producing adenoma.

Control subjects were fourteen healthy volunteers, eight females and six males, without Cushing's syndrome or any other endocrine disorder. None of the female volunteers was using oral anticonceptive drugs at the time of investigation.

\section{Peripheral blood mononuclear cells}

Blood $(40 \mathrm{ml})$ was drawn into heparinised tubes between $0800 \mathrm{~h}$ and $0900 \mathrm{~h}$ by venepuncture. PBMLs were isolated as described previously (9). The blood was diluted twofold with saline and layered over FicollHypaque (Pharmacia, Uppsala, Sweden). The PBML enriched interphase was isolated and washed twice with saline. The final cell pellet was resuspended in $15 \mathrm{ml}$ RPMI-1640 medium (Gibco Europe, Breda, The Netherlands), containing $15 \mathrm{mmol} / \mathrm{l}$ Hepes, $10 \%$ charcoaladsorbed fetal calf serum (Amstelstad/Flow, Zwanenburg, The Netherlands), $2 \mathrm{mmol} / \mathrm{l}$ glutamine, $100 \mathrm{U} / \mathrm{ml}$ penicillin, $100 \mathrm{mg} / \mathrm{ml}$ streptomycin and $1.5 \mathrm{mg} / \mathrm{ml}$ fungizone. The cells were incubated for $30 \mathrm{~min}$ at $37^{\circ} \mathrm{C}$ in a shaking water bath in order to remove endogenous cortisol. The cell suspension was centrifuged and resuspended in $15 \mathrm{ml}$ medium. This procedure was repeated twice more. Finally, the cells were resuspended at a density of $2.5-10 \times 10^{6}$ cells per $\mathrm{ml}$ in the medium.

\section{Whole cell dexamethasone binding assay}

The whole cell dexamethasone binding assay was performed as described previously by Molijn et al. (9). Briefly, incubation was started in a volume of $240 \mu \mathrm{l}$ $\left(0.5-2 \times 10^{6}\right.$ cells) containing $\left[{ }^{3} \mathrm{H}\right]$ dexamethasone at concentrations of 1.3 to $40 \mathrm{nmol} / \mathrm{l}$ without (total binding) and with (specific binding) a 400-fold excess of unlabelled dexamethasone. Two tubes without labelled dexamethasone were incubated under the same conditions for determination of cell number and viability at the end of the procedure. The tubes were incubated during $1 \mathrm{~h}$ at $30^{\circ} \mathrm{C}$ in a shaking water bath. The incubation was stopped by the addition of $2 \mathrm{ml}$ cold saline, followed by centrifugation and two washing steps. Finally, the cells were resuspended in $250 \mu \mathrm{l}$ medium. Radioactivity in $200 \mu \mathrm{l}$ of this suspension was counted in a liquid scintillation counter. Specific binding was calculated by subtracting non-specific binding from total binding. Receptor number and ligand affinity $\left(\mathrm{K}_{\mathrm{d}}\right)$ were calculated from the data using the method of Scatchard (10).

\section{Cortisol determinations}

At the same time as blood was withdrawn for the whole cell dexamethasone binding assay, extra blood was withdrawn for cortisol determinations. In the patients, two more blood samples were taken at $1700 \mathrm{~h}$ and $2200 \mathrm{~h}$ in order to investigate the circadian rhythm of cortisol concentrations. Patients were at basal rest during the day the samples were taken. Serum cortisol concentrations were determined using RIA kits obtained from DPC (Los Angeles, CA, USA). Intra- and interassay variations were below $8.0 \%$ and $9.5 \%$ respectively.

\section{Statistical analysis}

The results for serum cortisol concentrations, number of receptors and $K_{d}$ are reported as means \pm S.E.M. To 
Table 1 Differences in serum cortisol concentrations and cortisol receptor characteristics between patients with Cushing's syndrome $(n=13)$ and control subjects $(n=14)$

\begin{tabular}{|c|c|c|c|c|c|}
\hline & \multicolumn{2}{|c|}{ Cushing } & \multicolumn{2}{|c|}{ Controls } & \multirow[b]{2}{*}{$P$} \\
\hline & Mean & S.E.M. & Mean & S.E.M. & \\
\hline Serum cortisol $(\mathrm{nmol} / \mathrm{l})$ & 822 & 64.5 & 382 & 37.6 & $<0.001^{\star}$ \\
\hline $\begin{array}{l}\text { Number of receptors } \\
\text { per cell }\end{array}$ & 6339 & 417 & 6184 & 211 & 0.72 \\
\hline $\mathrm{K}_{\mathrm{d}}(\mathrm{nmol} / \mathrm{l})$ & 17.4 & 1.9 & 9.3 & 0.5 & $<0.001^{*}$ \\
\hline
\end{tabular}

* Statistically significant.

assess the relationships between cortisol concentrations and number of receptors or $\mathrm{K}_{\mathrm{d}}$, linear regression analysis was used.

\section{Results}

There was a statistically significant higher early morning serum cortisol concentration in patients with Cushing's syndrome compared with controls (Table 1). Although not all individual patients had early morning cortisol concentrations above the upper normal level $(800 \mathrm{nmol} / \mathrm{l})$, none of the patients with Cushing's syndrome had a diurnal rhythm of serum cortisol concentrations (data not shown).

Table 1 also shows that there were no differences in the number of receptors per cell between the two groups. On the other hand, there was a statistically significantly higher $\mathrm{K}_{\mathrm{d}}$ in the patient group compared with controls, indicating a lower affinity of the receptor for its ligand.

As shown in Table 2, neither in the patient group nor in the control group was there a statistically significant correlation between number of receptors per cell and serum cortisol concentrations. On the other hand, as shown in Fig. 1, there was a significant positive correlation between $\mathrm{K}_{\mathrm{d}}$ and serum cortisol concentrations in patients with Cushing's disease, which was not present in the control group.

Figure 2 shows the results of Scatchard analyses of the GR in one of the patients with pituitary-dependent Cushing's disease before and after successful transsphenoidal adenomectomy of the ACTH-secreting

Table 2 Correlations between serum cortisol concentrations and cortisol receptor characteristics in patients with Cushing's syndrome $(n=13)$ and in control subjects $(n=14)$.

\begin{tabular}{lcccrrr}
\hline & \multicolumn{2}{c}{ Cushing } & & \multicolumn{2}{c}{ Controls } \\
\cline { 2 - 3 } & $r$ & $P$ & & $r$ & $P$ \\
\hline Number of receptors per cell & 0.12 & 0.68 & & 0.50 & 0.07 \\
$\mathrm{~K}_{\mathrm{d}}(\mathrm{nmol} / \mathrm{l})$ & 0.59 & $0.03^{*}$ & & -0.02 & 0.95 \\
\hline
\end{tabular}

* Statistically significant. microadenoma. Although the basal morning serum cortisol concentration after remission was not much lower than during disease $(704 \mathrm{nmol} / \mathrm{l}$ vs $510 \mathrm{nmol} / \mathrm{l}$ respectively), the serum cortisol concentrations after treatment showed a diurnal rhythm, in contrast to those before treatment. The data in Fig. 2 indicate that while the treatment did not influence the number of receptors per cell measured in PBML from this patient, the ligand affinity did normalise after treatment.

\section{Discussion}

To our knowledge, GR down-regulation in patients with endogenous Cushing's syndrome has never been investigated. Therefore, we investigated 13 patients with endogenous Cushing's syndrome with respect to GR characteristics. We found no receptor down-regulation, but a significantly lower ligand affinity in patients compared with controls. A possible explanation could be that high concentrations of GC influence the outcome of the whole cell dexamethasone binding assay. However, a previous study by our group (9) especially investigated the effect of exposure to high cortisol concentrations on the number of receptors and the ligand affinity in this assay. It was shown that only $3.3 \%$ of endogenous cortisol remained specifically bound to the receptor. Moreover, incubation in the presence of high doses of cortisol affected both receptor number ('down-regulation') and ligand affinity ('decreased affinity'). In contrast, the results from this study show an isolated lowering in ligand affinity, without effects on receptor number. In addition, the absolute cortisol concentrations in the patients with Cushing's syndrome were much lower than the concentrations administered in the in vitro experiments performed by Molijn et al. (9). Since the lowered ligand affinity does not seem to be caused by the presence of cortisol in the whole cell dexamethasone binding assay, these results possibly reflect receptor modification in response to the exposure to continuously high cortisol levels, as present in patients with Cushing's syndrome who lack a normal diurnal rhythm of serum cortisol concentrations. This assumption is substantiated by the fact that in one patient a normalisation of the ligand affinity was observed after complete remission of the disease.

The ability of GCs to act on target tissues requires the presence of intact and sufficient numbers of GRs (3). Many studies investigating GR numbers have been performed, on the basis of the hypothesis that receptor down-regulation might be an additional form of negative feedback, protecting against the continued signal elicited by ligand in cases of hypercorticolism or other forms of GC excess (6). In several studies, a direct correlation between GR number and the cell's sensitivity to GCs was found $(11,12)$. Furthermore, a receptor down-regulation in reaction to GC therapy was demonstrated in cell cultures and animals, including humans 


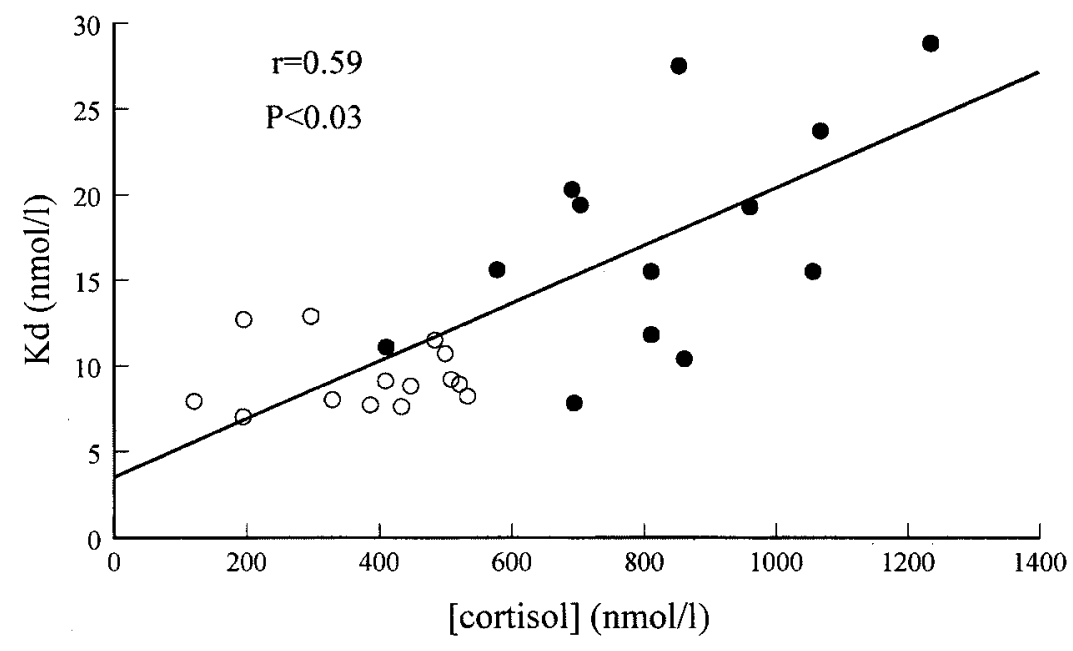

Figure 1 Relationship between serum cortisol concentrations and $\mathrm{K}_{d}$ in PBMLs in 13 patients with Cushing's syndrome $(\bullet)$ and 14 healthy controls $(O)$.
$(7,8)$. The possible mechanism of this receptor downregulation is poorly understood. There is evidence for an enhanced receptor degradation $(13,14)$ in vitro but nothing is known about accelerated GR turnover in vivo. Furthermore, many investigations were performed on GR mRNA expression levels. There is evidence that GC treatment modulates GR expression in a number of tissues and cell types, and that down-regulation occurs at both transcriptional, post-transcriptional and/or posttranslational levels $(6,13,15)$. Moreover, most of the data available at present concern in vitro studies or results obtained after administration of pharmacological amounts of exogenous GC.

Little is known about the physiological actions of GC on receptor number or affinity. An elegant example in this respect would be the syndrome of generalised GC resistance. GC resistance is a rare disease, in which an extreme insensitivity of the target tissues to GC action leads to a clinical syndrome characterised by signs and symptoms of secondary overproduction of adrenal androgens and mineralocorticoids. Up until now, the molecular basis of the clinical syndrome has been elucidated in only four kindreds. In three of these four (16-18), different mutations in the hormone binding domain of the GR gene were found, while in the fourth kindred (19) a heterozygous splice site deletion at the $3^{\prime}$ boundary of exon 6 of the GR gene appeared to be the cause of the syndrome. In the latter kindred, the splice site deletion resulted in an unstable mRNA with only half the number of receptors on PBMLs as a final result. In all of these patients, the HPA-axis was set at a higher level, resulting in higher ACTH and cortisol concentrations. None of these patients showed any signs or symptoms mimicking an Addisonian clinical picture, meaning that there was a sufficient compensation of cortisol concentrations as a result of the increased HPA

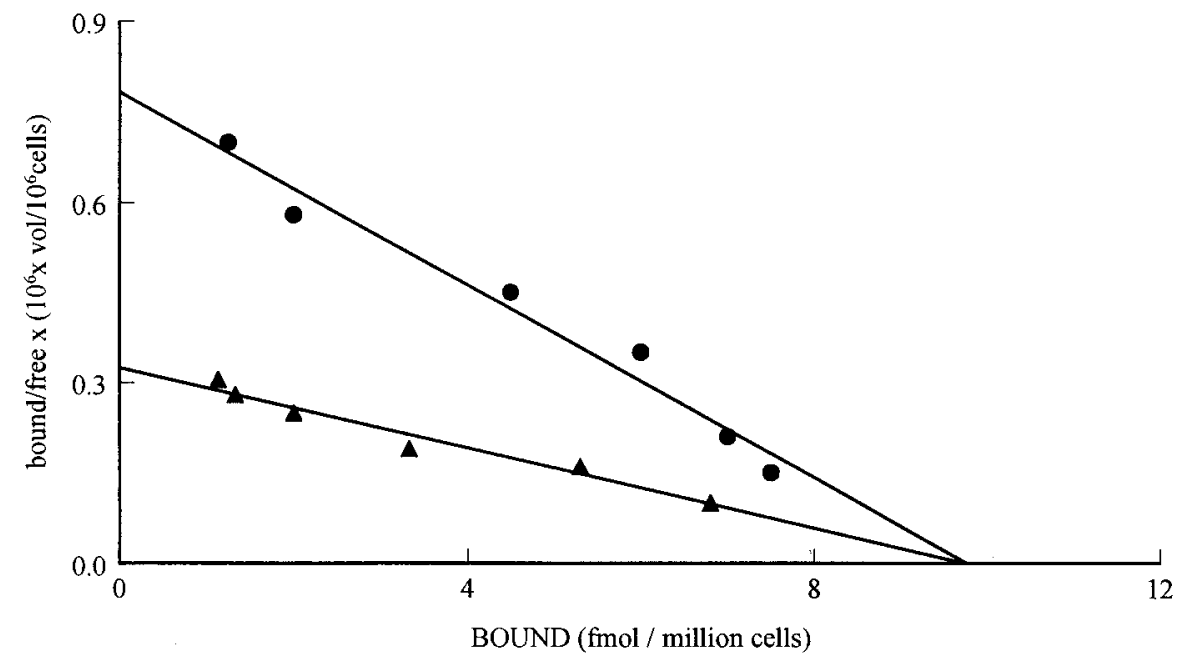

Figure 2 Whole cell dexamethasone binding assays of PBML in a patient with Cushing's disease before ( $\mathbf{\Delta})$ and after treatment. 
activity. In none of the patients was receptor upregulation demonstrated, especially not in the patient with only half the number of receptors as a result of the splice site deletion in the GR gene. In these cases, it can be concluded that receptor up-regulation is not an additional feedback system in cases of relative cortisol shortage.

On the other hand, one might ask why people treated with GCs develop Cushing's syndrome; sufficient receptor down-regulation should protect a patient from developing side-effects of GC treatment. Nevertheless, many patients treated with GCs have serious adverse effects.

It can be concluded that there is no GR downregulation in patients with endogenous Cushing's syndrome, but that a diminished ligand affinity of yet unknown cause might partially protect the cells from the high cortisol levels. An explanation for the mechanism involved is currently unknown: differences in receptor chaperoning/recycling might be responsible for the lower affinity in the absence of a variation in receptor number. Nevertheless, this protecting mechanism seems to be insufficient, because all patients showed clinical signs and symptoms of GC excess.

\section{References}

1 Munck A \& Guyre PM. Glucocorticoid physiology, pharmacology and stress. In Steroid Hormone Resistance: Mechanism and Clinical Aspects. Advances in Experimental Medicine and Biology, vol 196. pp 81-96. Eds GP Chrousos, DL Loriaux \& MB Lipsett. New York: Plenum Press, 1986.

2 Chrousos GP. The hypothalamic-pituitary-adrenal axis and immune-mediated inflammation. New England Journal of Medicine $19953221351-1362$.

3 Bamberger CM, Schulte HM \& Chrousos GP. Molecular determinants of glucocorticoid receptor function and tissue sensitivity to glucocorticoids. Endocrine Reviews 199517 245-261.

4 Evans RM. The steroid and thyroid hormone receptor superfamily. Science $1988240889-892$.

5 Giguere V, Hollenberg SM, Rosenfeld MG \& Evans RM. Functional domains of the human glucocorticoid receptor. Cell 198546 645-652.

6 Brönnegård M. Steroid receptor number, individual variation and downregulation by treatment. American Journal of Respiratory and Critical Care Medicine 1996154 528-533.
7 Silvia CM, Powell-Oliver FE, Jewell CM, Sar M, Allgod VE \& Cidlowski JA. Regulation of the human glucocorticoid receptor by long-term and chronic treatment with glucocorticoids. Steroids $199459436-442$.

8 Knutsson U, Stierna P, Carlstedt-Duke J, Carlström K, Marcus C \& Brönnegård $\mathrm{M}$. Effects of intranasal glucocorticoids on endogenous glucocorticoid peripheral and central function. Journal of Endocrinology 1995144 301-310.

9 Molijn GJ, Koper JW, van Uffelen CJC, de Jong FH, Brinkmann AO, Bruining HA et al. Temperature induced down-regulation of the glucocorticoid receptor in peripheral blood mononuclear leukocyte in patients with sepsis or septic shock. Clinical Endocrinology 199543 197-203.

10 Scatchard G. The attractions of proteins for small molecules and ions. Annals of the New York Academy of Sciences 194951 660672 .

11 Gehring U, Mugele K \& Ulrich J. Cellular receptor levels and glucocorticoid responsiveness of lymphoma cells. Molecular and Cellular Endocrinology 198436 107-112.

12 Vanderblid JN, Miesfeld R \& Yamamoto KR. Intracellular receptor concentration limits glucocorticoid-dependent enhancer activity. Molecular Endocrinology 19871 68-76.

13 Dong Y, Poelinger L, Gustafsson JA \& Okret S 1988 Regulation of glucocorticoid receptor expression: evidence for transcriptional and posttranslational mechanisms. Molecular Endocrinology 1988 2 1256-1264.

14 Okret S, Dong Y, Brönnegård M \& Gustafsson JA. Regulation of glucocorticoid receptor expression. Biochimie 199173 51-59.

15 Burnstein KL, Bellingham DL, Jewell CM, Powell-Oliver FE \& Cidlowski JA. Autoregulation of the glucocorticoid receptor gene expression. Steroids $19915652-58$.

16 Hurley DM, Accili D, Stratakis CA, Karl M, Vamvakopoulos N, Rorer $\mathrm{E}$ et al. Point mutation causing a single amino acid substitution in the hormone binding domain of the glucocorticoid receptor in familial glucocorticoid resistance. Journal of Clinical Investigation 199187 680-686.

17 Malchoff DM, Brufsky A, Reardon G, McDermott P, Javier EC, Bergh $\mathrm{CH}$ et al. A mutation of the glucocorticoid receptor in primary cortisol resistance. Journal of Clinical Investigation 1993 91 1918-1925.

18 Karl M, Lamberts SWJ, Koper JW, Katz A, Huizenga NATM, Kino T et al. Cushing's disease preceded by generalized glucocorticoid resistance: clinical consequences of a novel, dominant-negative glucocorticoid receptor mutation. Proceedings of the Association of American Physicians 108 296-307.

19 Karl M, Lamberts SWJ, Detera-Wadleigh SD, Enico IJ, Stratakis CA, Hurley DM et al. Familial glucocorticoid resistance caused by a splice site deletion in the human glucocorticoid receptor gene. Journal of Clinical Endocrinology and Metabolism 199376 683-689.

Received 6 July 1999

Accepted 19 January 2000 